$\Phi=$

\title{
Antipyretic, analgesic and anti-inflammatory activity of the meth- anol Mimosa himalayana extract
}

\author{
Md. Imran Hossain ${ }^{1}$, Md. Khairul Bashar ${ }^{1}$, Mohammed Ibrahim¹, Muhammad Torequl Islam ${ }^{1,2} *$ \\ ${ }^{1}$ Department of Pharmacy, Faculty of Science \& Engineering, Southern University Bangladesh, Mehedibag (Chittagong)-4000, Bangladesh \\ ${ }^{2}$ Postgraduate Program in Pharmaceutical Sciences, Federal University of Piauí, Teresina (Piauí)-64.009-550, Brazil \\ *Corresponding author E-mail:rbiotufpi.br@gmail.com
}

\begin{abstract}
The aim of the study was to evaluate antipyretic, analgesic and anti-inflammatory activities of the methanol extract of Mimosa himalayana Gamble (Fabaceae) along with a preliminary phytochemical screening. The antipyretic and analgesic effects were tested in Swiss mice, while anti-inflammatory in egg albumin, taking paracetamol, diclofenac sodium and acetyl salicylic acid as standards, respectively. The results suggest that, the crude stem extract of $M$. himalayana revealed the presence of alkaloids, glycosides, saponins and gums. It exhibited antipyretic and analgesic activity at 200 and $400 \mathrm{mg} / \mathrm{kg}$, while anti-inflammatory at 40,80 and $160 \mu \mathrm{g} / \mathrm{mL}$ in the test systems. The activities were significant $(\mathrm{p}<0.05)$ in comparison to the negative control group with a high dose/concentration-mediated higher response manner. We suppose the alkaloids and glycosides may contribute its anti-inflammatory potential, which may link to the antipyretic and analgesic effects of the $M$. himalayana. In conclusion, $M$. himalayana may be one of the best sources of plant-based medicines, especially anti-inflammatory agents.
\end{abstract}

Keywords: Medicinal Plant; Phytochemical Screening; Pharmacological Activities.

\section{Introduction}

Fabaceae (also known as legume, pea, bean or pulse family) is a large and economically important family of flowering plants (http://www.zipcodezoo.com/Key/Plantae/Fabaceae_Family.asp). According to the Royal Botanical Gardens, it is the third largest family of flowering plants with 730 genera and over 19,400 species. Mimosa himalayana Gamble (synonym: Mimosa rubricaulis) (Box 1 and Figure 1) is a member of the family Fabaceae, which is widely distributed in Bangladesh. The paste of the root of this plant is externally used on the testicles for the treatment of onesided hydrocele (Eksira) (http://zipcodezoo.com/Plants/M/Mimosa_himalayana/Default.asp ). In a recent study, the crude methanolic extract of $M$. himalayana has been found to act against Bacillus subtilis, Pseudomonas aeruginosa, Escherichia coli, Klebsiella pneumonia, Aspergillus nigar and A. flavus (Mahmood et al. 2012).

A

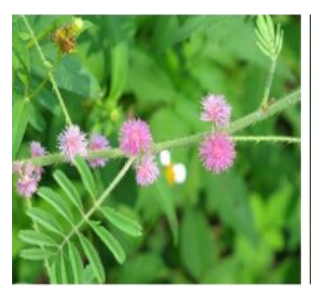

B

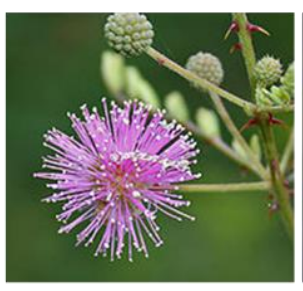

C

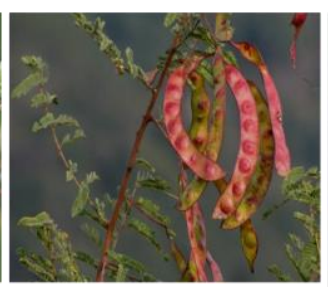

Box 1. Plant taxonomy

Kingdom: Plantae Division: Tracheophyta

Class: Magnoliopsida

Order: Fabales

Family: Fabaceae

Genus: Mimosa

Species: himalayana

Fig. 1: Mimosa himalayana Gamble. [A. Aerial Parts, B. Flower, C. Fruits, D. Ripe Fruit and E. Seeds].

The contribution of medicinal plants in the modern medicines is vast and increasing day by day. It is due to the presence of abundant phytochemicals in a small amount of plant sample (Rao and
Arora 2014; Islam et al. 2016a). This study aimed to evaluate an antipyretic, analgesic and anti-inflammatory activity of the meth- 
anolic stem extract of $M$. himalayana. Additionally, a preliminary phytochemical evaluation was also done.

\section{Materials and methods}

\subsection{Collection of plant materials and extract prepara- tion}

The stems of $M$. himalayana, collected from the Bhatiyari and Pahartoli of Chittagong, Bangladesh in June, 2012 were identified by the Taxonomist by Bangladesh Forest Research Institute (FRI), Chittagong. After collection, the plant materials were washed with running tap water and dried at room temperature not exceeding $50^{\circ} \mathrm{C}$. The dry materials were ground into coarse powders and kept in an amber-colored airtight container until the extraction commenced. $400 \mathrm{gm}$ of the powdered materials was soaked in 1600 $\mathrm{mL}$ absolute methanol (Merck, India) containing amber color glass container with an occasionally shaking for 7 days.After the elapsed time, the content was filtered through surgical cotton; following to the Whatmann filter paper (No. 1) and concentrate at room temperature (using an air cooler). The yield was $7.19 \%$. The concentrated crude extract was preserved in a small amber color glass container at room temperature.

\subsection{Reagents and chemicals}

Standards and other reagents and chemicals used in this study were collected from Sigma Aldrich (USA).

\subsection{Experimental animals}

For antipyretic and analgesic study, Swiss albino mice of either sex (age: 6-7 weeks; body weight: 25-30 g) were collected from the Animal Resources Branch of the International Centre for Diarrheal Disease and Research, Bangladesh (ICDDR,B). The mice were acclaimed for 7 days in the laboratory prior to study under standard environmental conditions (temperature: $25 \pm 1{ }^{\circ} \mathrm{C}$; relative humidity: $55-66 \%$ and $12 \mathrm{~h}$ light/dark cycle) and free to access to ICDDR,B formulated diet and water ad libitum. The experimental protocol was approved by the ethical committee of the Pharmacy Department of Southern University Bangladesh (Number: SUB-999-08-25).

\subsection{Preliminary phytochemical investigation}

A preliminary phytochemical screening of the crude methanol extract of $M$. himalayana (MEMH) was done according to the guidelines of Evans and Trease (2002) and Ali (2009).

\subsection{Pharmacological studies}

\subsection{Preparation of test sample}

Tween $80(0.05 \%)$ dissolved in $0.9 \% \mathrm{NaCl}$ solution was served as a vehicle for the crude extract and standards.

\subsection{Antipyretic activity}

This study was conducted with the slight modification of the method described by Sultana et al (2015). Briefly, 20\% aqueous suspension of Brewer's yeast $(10 \mathrm{~mL} / \mathrm{kg})$ was administered subcutaneously (s.c.) to induce pyrexia in the animals. Animals that showed an increase in temperature of at least $0.7^{\circ} \mathrm{C}$ were used for the experiment. The animals were fasted overnight before the experimentation and grouped (7 animals in each group) as - vehicle (negative control), paracetamol $(150 \mathrm{mg} / \mathrm{kg}$ via oral gavage), and MEMH 200 and $400 \mathrm{mg} / \mathrm{kg}$ (via oral gavage). Rectal temperature $\left({ }^{\circ} \mathrm{F}\right)$ was recorded at 1,2 and $3 \mathrm{~h}$ after the treatment.

\subsection{Analgesic activity}

The analgesic activity was carried out by using formalin-induced writhing method (Pourmotabbed et al. 2010). By this time, Swiss mice ( 7 in each group) were randomly divided into - vehicle (negative control, p.o.), diclofena sodium ( $25 \mathrm{mg} / \mathrm{kg}$, intraperitoneal), and MEMH 200 and $400 \mathrm{mg} / \mathrm{kg}$ (p.o.). Formalin solution (5\%, i.p.) was administered to each animal after 30 minutes of the sample/controls treatment and the number of squirms (writhing) were counted for 5 minutes.

\subsection{In vitro anti-inflammatory activity (hypo-saline- induced egg albumin denaturation test)}

The anti-inflammatory (in vitro) of MEMH was carried out according to Ripon et al (2016). Briefly, 1\% egg albumin was constituted in phosphate buffer saline solution (PBS, pH 7.4). The reaction mixture contains: $1 \mathrm{~mL}$ PBS, $2 \mathrm{~mL}$ hypo-saline $(0.36 \%)$ and $0.5 \mathrm{~mL}$ of the test sample. Acetyl salicylic acid (ASA) and previously mentioned vehicle were taken as positive and negative (NC) controls, respectively. MEMH was tested at 40, 80 and 160 $\mu \mathrm{g} / \mathrm{mL}$, while ASA at $80 \mu \mathrm{g} / \mathrm{mL}$ concentrations. After the incubation at $37{ }^{\circ} \mathrm{C}$ for $30 \mathrm{~min}$, reaction mixtures were centrifuged (at $4000 \mathrm{~g}$ for $5 \mathrm{~min}$ ) and the supernatant was collected for spectrophotometric analysis at $560 \mathrm{~nm}$. Activity was measured by the following equation:

$\%$ inhibition of protein denaturation $=100-[\{($ absorbance of test solution $) \div($ absorbance of $\mathrm{NC})\} \times 100$ ]

\section{Statistical analysis}

Values are mean \pm SD (standard deviation). The data were analyzed by means of analysis of variance (ANOVA) followed by $t$ Student-Newman-Keuls's as post hoc test using the GraphPad Prism software (version 6.0) considering 95\% confidence interval at $\mathrm{p}<0.05$.

\section{Results}

\subsection{Phytochemical test}

The MEMH revealed the presence of alkaloids, glycosides, saponins and gums.

\subsection{Antipyretic activity}

MEMH at 200 and $400 \mathrm{mg} / \mathrm{kg}$ reduced the rectal temperature at 1 , 2 and $3 \mathrm{~h}$ in the pyrexic mice when compared to the basal and control temperatures. MEMH at $400 \mathrm{mg} / \mathrm{kg}$ reduced rectal temperature by $1.33 \pm 0.19$ and $1.55 \pm 0.24$ at 2 and $3 \mathrm{~h}$, respectively. The standard paracetamol at $150 \mathrm{mg} / \mathrm{kg}$ was also significant ( $\mathrm{p}$ $<0.05$ ) reduced the rectal temperature of the animals in a timedependent manner. Although, the activity of MEMH at 200 and $400 \mathrm{mg} / \mathrm{kg}$ doses was lower than the paracetamol group, but MEMH at $400 \mathrm{mg} / \mathrm{kg}$ at 2 and $3 \mathrm{~h}$ was found to reduce the rectal temperature more than the paracetamol group at 1 and $2 \mathrm{~h}$, respectively (Table 1).

\subsection{Analgesic activity}

The diclofenac sodium and both doses of MEMH were found to reduce the number of writhing with an increase in protection as compared to the NC group. MEMH at $400 \mathrm{mg} / \mathrm{kg}$ reduced writhing and increased protection by $54.75 \%$ and $45.25 \%$, respectively. Although, the activity of MEMH at 200 and $400 \mathrm{mg} / \mathrm{kg}$ was lower than the standard group, but MEMH with both doses significantly reduced writhing and increased in protection of the test animals when compared to the NC group (Table 2). 
Table 1: Effect of Crude Extract/Controls in Yeast-Induced Pyrexia Animals

\begin{tabular}{lllll} 
Treatment & Dose & \multicolumn{3}{l}{ Reduction of temperature $\left({ }^{0} \mathrm{~F}\right)$ in compari- } \\
son to basal rectal temperature
\end{tabular}

Table 2: Effects of Crude Extract and Controls in Formalin-Induced Mice

\begin{tabular}{|c|c|c|c|}
\hline Treatment & Dose & Writhing & $\%$ protection \\
\hline $\mathrm{NC}$ & $10 \mathrm{~mL} / \mathrm{kg}$ & $33.35 \pm 1.78$ & 0 \\
\hline Diclofenac sodium & $25 \mathrm{mg} / \mathrm{kg}$ & $\begin{array}{l}13.91 \pm \\
2.13^{*}\end{array}$ & $58.29^{*}$ \\
\hline \multirow{2}{*}{ MEMH } & $200 \mathrm{mg} / \mathrm{kg}$ & $\begin{array}{l}21.04 \pm \\
2.34 *\end{array}$ & $36.91^{*}$ \\
\hline & $400 \mathrm{mg} / \mathrm{kg}$ & $\begin{array}{l}18.26 \pm \\
3.01^{*}\end{array}$ & $45.25^{*}$ \\
\hline \multicolumn{4}{|c|}{$\begin{array}{l}\text { Values are mean } \pm \text { standard deviation }(\mathrm{SD})(\mathrm{n}=7), * \mathrm{p}<0.05 \text { when com- } \\
\text { pared to the } \mathrm{NC} \text { (Tween } 80(0.05 \%) \text { dissolved in } 0.9 \% \mathrm{NaCl} \text { solution); } \\
\text { MEMH: methanol extract of } M . \text { himalayana. }\end{array}$} \\
\hline
\end{tabular}

\subsection{Anti-inflammatory activity}

Table 3 suggests that, ASA at $80 \mu \mathrm{g} / \mathrm{mL}$ and MEMH at all concentrations inhibited hypotonic solution-induced protein denaturation in egg albumin. The highest inhibition of protein denaturation was observed with ASA 80 and MEMH $160 \mu \mathrm{g} / \mathrm{mL}$ by $76.74 \pm$ 1.14 and $51.55 \pm 0.13 \%$, respectively. MEMH at 40 and $80 \mu \mathrm{g} / \mathrm{mL}$ exerted almost similar percentages of protein denaturation.

Table 3: In-Vitro Anti-Inflammatory Activity of Crude Extract and Controls

\begin{tabular}{lll}
\hline Treatment & Concentration & $\begin{array}{l}\text { \% inhibition of protein dena- } \\
\text { turation }\end{array}$ \\
\hline NC & $0.5 \mathrm{~mL}$ & $00.00 \pm 0.01$ \\
ASA & $80 \mu \mathrm{g} / \mathrm{mL}$ & $76.74 \pm 1.14^{*}$ \\
& $40 \mu \mathrm{g} / \mathrm{mL}$ & $46.51 \pm 0.07 *$ \\
MEMH & $80 \mu \mathrm{g} / \mathrm{mL}$ & $48.06 \pm 1.01 *$ \\
& $160 \mu \mathrm{g} / \mathrm{mL}$ & $51.55 \pm 0.13 *$ \\
Values are mean \pm standard deviation $(\mathrm{SD})(\mathrm{n}=7) ;{ }^{*} \mathrm{p}<0.05$ when com- \\
pared to the NC (Tween $80(0.05 \%)$ dissolved in $0.9 \% \mathrm{NaCl}$ solution); \\
ASA: acetyl salicylic acid; MEMH: methanol extract of M. himalayana.
\end{tabular}

\section{Discussion}

An inhibition of prostaglandin synthesis is considered the mechanism of antipyretic action of paracetamol (a selective cyclooxygenase, especially COX-2 inhibitor). However, there are several mediators for pyrexia and the inhibition of them is responsible for the antipyretic effect of any substance (Clark 1979). Furthermore, the chronic prostaglandin synthesis may produce an inflammatory and algesia in experimental animals (Sultana et al. 2015). Although, a low level of chronic inflammatory response is beneficial, but at the high or severe condition it may cause harm to the host (Islam et al. 2016b). The plant-derived constituents, such as alkaloids and glycosides are known to produce a number of biological activities, including antipyretic, analgesic, anti-inflammatory, and so on (Musa et al. 2008; Nur et al. 2015; Sultana et al. 2015). For an example, in a study, Sidaye et al (2011) reported that the antipyretic action of the plant crude extract can inhibit the prostaglandin synthesis in experimental animals. In this study, the MEMH revealed the presence of alkaloids and glycosides may contribute antipyretic, analgesic and anti-inflammatory activities.

\section{Conclusion}

The methanol extract of $M$. himalayana exhibited antipyretic, analgesic and anti-inflammatory activities in the test systems. The anti-inflammatory response of the extract may be plugged in its antipyretic and analgesic. We suppose, the plant containing alkaloids and glycosides may be the responsible secondary metabolites for the observed biological responses. Further researches are needed to isolate the phytoconstituents and claim the biological activities and their possible mechanism of actions.

\section{Conflict of interest}

None declared.

\section{References}

[1] http://www.zipcodezoo.com/Key/Plantae/Fabaceae_Family.asp.

[2] http://zipcodezoo.com/Plants/M/Mimosa_himalayana/Default.asp.

[3] Mahmood A, Mahmood A, Qureshi RA. Antimicrobial activities of three species of family mimosaceae. Pak J Pharm Sci 2012; 25:203206.

[4] Rao VR, AroraRK. Rationale for conservation of medicinal plants. pp. 7-22 in Batugal PA et al. (Eds.) Medicinal Plants Research in Asia. Vol 1: the Framework and Project Work Plans. International Plant Genetic Resources Institute (IPGRI), KualaLumpur. 2014

[5] Islam MT, Mata AMOF, Aguiar RPS, Paz MFCJ, Alencar MVOB, Melo-Cavalcante AAC. Therapeutic potential of essential oils focusing on diterpens. Phytother Res 2016a; 30:1420-1444. https://doi.org/10.1002/ptr.5652.

[6] Evans WC, Trease WC. Pharmacognosy. London: WB Saunders Ltd. 2002; pp. 32, 33, 95-99, 512, 547.

[7] Ali M. Text Book of Pharmacognosy. New ed. CBS Publishers and Distributors. New Delhi, India. 2009; pp. 96, 97, 140, 283.

[8] Sultana N, Islam MT, Alencar MVOB, Silva SWC, Chowdhury MU, Melo-Cavalcante AAC, Freitas RM. Phyto-pharmacological screenings of two Rubiaceae family plants. Afric J Pharm Pharmacol 2015; 9:775-782. https://doi.org/10.5897/AJPP2015.4313.

[9] Pourmotabbed A, Farshchi A, Ghiasi G, Khatabi PM. Analgesic and anti-inflammatory activity of Teucriumchamaedrysleaves aqueous extract in male rats. Iranian J Basic Med Sci 2010; 13:119125 .

[10] Ripon SS, Mahmood A, Chowdhury MMU, Islam MT. Evaluation of antioxidant, anti-inflammatory capacities and a possible antiatherothrombosis activity of the methanol leaf extract of Clerodenrum viscosum. Adv Biomed Pharm 2016; 3:366-372. https://doi.org/10.19046/abp.v03i06.02.

[11] Clark WG. Mechanism of antipyretic action. General Pharmacology: The Vascular System 1979; 10:71-77. https://doi.org/10.1016/0306-3623(79)90038-7.

[12] Islam MT, Alencar MVOB, Mata AMOF, Paz MFCJ,Matos LA, Sousa JMC, Melo-Cavalcante AAC. Coffee: A health fuel-blot popular drinking. Int $\mathrm{J}$ Pharm PharmSci 2016b; 8:1-7. https://doi.org/10.22159/ijpps.2016v8i12.14510.

[13] Musa YM, Haruna AK, Ilyas M, Yaro AH, Ahmadu AA, Usman H. Phytochemical, analgesic and anti-inflammatory effects of the ethylacetate extract of the leaves of Pseudocedrella kotschyii. Afr J Trad Compliment Alt Med 2008; 5:92-96. https://doi.org/10.4314/ajtcam.v5i1.31261.

[14] Nur T, Islam MT, Alam S, M. Chowdhury MMU, Melo-Cavalcante AAC, Freitas RM. Pharmacological investigations of organic crude fractions of Dysophylla auricularia. Orient Pharm Exp Med 2015; 15:207-215. https://doi.org/10.1007/s13596-015-0190-x.

[15] Sidaye RV, Dhanawade AE, Mansha K, Aishwarya G. Synthesis anti-microbial and antimycobacterial activity of nicotinic-acid hydrazide derivatives. Curr Pharm Res 1973; 1:135-139. 